\title{
The establishment of a national tissue bank for inflammatory bowel disease research in Canada
}

\author{
Stephen M Collins MD RFCPUK FRCPC ${ }^{1}$, Kevin McHugh PhD2, \\ Ken Croitoru MD FRCPC ${ }^{1}$, Micheal Howorth BA MSW ABD ${ }^{2}$
}

\begin{abstract}
SM Collins, K McH ugh, K Croitoru, M H oworth. The establishment of a national tissue bank for inflammatory bowel disease research in C anada. C an J G astroenterol; 17(2):107. 109.

The Crohn's and Colitis Foundation of Canada (CCFC) has established a national bank for tissue, serum and blood from patients with inflammatory bowel disease (IBD). Investigators from across the country submit material to the bank together with clinical data. Investigators may access their own patient information from the bank for their own study purposes, but the distribution of tissue is restricted to specific C CFC-funded projects. C urrently, tissues are being collected from newly diagnosed, untreated IBD patients to support a recent initiative aimed at characterizing microbes in colonic and ileal biopsies from such patients. In the future, criteria for the submission of tissue will be tailored to specific research questions. This bank is believed to be the first national bank of its kind dedicated to research in Crohn's disease and ulcerative colitis.
\end{abstract}

Key Words: C rohn's disease; Database; Epidemiology; Genetics; M icrobes; U Icerative colitis

T he $\mathrm{C}$ rohn's and C olitis Foundation of C anada (C CFC) is a registered $\mathrm{C}$ anadian charity whose mission is to "find the cure" for inflammatory bowel disease (IBD). Its highest priority is fundraising for research through the collaborative efforts of volunteers across $\mathrm{C}$ anada. The Foundation invests nearly three million dollars (Canadian) in research on an annual basis. In addition to funding grants-in-aid, the Foundation al so funds a national IBD research network - The CCFC IBD $\mathrm{N}$ etwork - to initiate and oversee larger projects whose scope exceeds those of individual or group grants that are funded through its grant-in-aid program. Recently, the N etwork established a national tissue and data bank to support (via tissue and associated patient data) IBD research in $C$ anada. This bank is believed to be the first of its kind in the world.

\section{THE CCFC IBD RESEARCH NET WORK}

The N etwork was launched in 1998 at the recommendation of CCFC's Strategic Initiatives Committee, to assist the Foundation in its goal to find the cause(s) of IBD by:

- Identifying and supporting research with a scope that exceeds that normally funded by the Foundation's individual or group grants.

\section{Constitution d'une banque nationale de tissus pour la recherche sur les maladies inflamma- toires de l'intestin au C anada}

\begin{abstract}
La Fondation canadienne des maladies inflammatoires de l'intestin a constitué une banque nationale de tissus, de sérums et de sang provenant de patients atteints d'une maladie inflammatoire de l'intestin (MII). Des chercheurs de partout au pays fournissent à la banque des prélèvements biologiques accompagnés de données cliniques. Les chercheurs peuvent avoir accès aux renseignements concernant leurs propres patients à des fins de recherche personnelle, mais la distribution de tissus est limitée aux projets financés par la Fondation. A ctuellement, on collecte des tissus provenant de patients non traités, chez qui une M II vient d'être diagnostiquée afin de soutenir une nouvelle initiative visant à caractériser la flore microbienne observée dans les prélèvements du côlon et de l'iléon de ces patients. À l'avenir, la collecte de tissus se fera en fonction de certaines questions de recherche. Le service serait la première banque nationale du genre, consacrée à la recherche sur la maladie de $C$ rohn et la rectocolite hémorragique.
\end{abstract}

- Fostering large scale collaborative research across C anada including the collection, storage and subsequent

distribution of patient tissue and data on a national scale.

The C CFC N etwork is comprised of clinicians and scientists representing institutions across $\mathrm{C}$ anada, and was chaired from 1998 to 2002 by Dr Stephen C ollins of M cM aster U niversity in $\mathrm{H}$ amilton, O ntario. The function of this committee was to identify projects that met the $\mathrm{N}$ etwork's terms of reference, and to identify strategies to attract appropriate investigators (who may not even consider themselves to be gastrointestinal researchers). The first $\mathrm{N}$ etwork project was a large doubleblind multicentre study on the efficacy of antibiotics in Crohn's disease, and performed under the leadership of Drs Hilary Steinhart and Gordon Greenberg from the U niversity of Toronto (O ntario), and Dr Brian Feagan from the U niversity of Western O ntario (London). The study was supported by CCFC as well as by a collaborative grant from A straZeneca $\mathrm{C}$ anada. The results of the study showed that the addition of ciprofloxacin and metronidazole to treatment with budesonide was ineffective in inducing remission in patients with C rohn's disease of the terminal ileum and/or the right colon.

${ }^{1}$ D ivision of $\mathrm{G}$ astroenterology, M cM aster U niversity M edical C entre, $\mathrm{H}$ amilton, $\mathrm{O}$ ntario; ${ }^{2} \mathrm{C}$ rohn's and $\mathrm{C}$ olitis $\mathrm{F}$ oundation of $\mathrm{C}$ anada, $\mathrm{T}$ oronto, O ntario

Correspondence and reprints: Dr Stephen C ollins, C rohn's and C olitis Foundation of C anada Inflammatory Bowel D isease N etwork, Division of G astroenterology, Room 4W 8, M cM aster U niversity M edical C entre, 1200 M ain Street W est, H amilton, O ntario L 8N $3 Z 5$.

Telephone 905-521-2100 ext 75255, fax 905-521-4958, e-mail scollins@mcmaster.ca 
The second study initiated by the $\mathrm{N}$ etwork aimed at establishing a national registry of IBD patients in Canada. This project was prompted not only by the obvious need for data on the incidence and prevalence of IBD in Canada, but also by the work of $\mathrm{Dr} C$ harles Bernstein and coworkers who used data from the $C$ anadian province of $M$ anitoba's single health insurer ( $\mathrm{M}$ anitoba $\mathrm{H}$ ealth) to determine the incidence and prevalence of IBD (1). This database has subsequently been used to calculate direct costs (2), cancer risk (3) and drug use (4) of IBD patients in that province. A team consisting of $\operatorname{Dr}$ Bernstein ( $M$ anitoba), Dr Sutherland (Alberta) and $\mathrm{Dr}$ Irvine (O ntario) has been assembled to determine the extent to which administrative health data can be used in other $\mathrm{C}$ anadian provinces to determine the incidence and prevalence of IBD in C anada. The preliminary work from Ontario was just published by Dr Irvine's group (5), demonstrating the utility of this method in other provinces.

The third N etwork project, prompted by the Foundation's challenge of finding the cause(s) of IBD, addressed the question of a microbial etiology of these disorders. U nder the guidance of the CCFC Network Committee member Dr Philip Sherman, several experts in enteric microbiology were invited to attend a think tank in January, 1999 to discuss the feasibility of examining a microbial etiology of IBD. The Network committee was persuaded that such an examination was indeed feasible given the developments in the molecular identification of microbes, and in 2001 announced a request for research applications (RFA ). A n international panel of experts evaluated the submissions and two projects were selected for support. One is from $\mathrm{Dr}$ G erald Tannock at the U niversity of A Iberta in Edmonton. Dr Tannock will examine mucosa-associated flora from inflamed and noninflamed regions of the ileum and colon of newly diagnosed but untreated patients with Crohn's disease and ulcerative colitis. Dr Ernest Seidman and his collaborators from the $U$ niversity of $M$ ontreal in $Q$ uebec will examine tissue from IBD patients for evidence of infection with cytomegalovirus, measles and parmyxoviruses, M ycobacterium avium intracellulare, as well as $\mathrm{C}$ ampylobacter and $\mathrm{H}$ elicobacter species.

During the N etwork meetings through 1999 and 2000, where discussion surrounded the above-described RFAs, it became apparent that the success of this undertaking would be as much dependent upon the source and nature of the tissue studied as it would on technology. It was repeatedly stressed that this 'gold standard' tissue material be collected and stored in a standardized, regulated manner. A nother strong sentiment was that no single institution should be made responsible for the administration of the collection and distribution of the tissue.

A decision was made for the $\mathrm{N}$ etwork to investigate ways of developing an independent organization and infrastructure to secure and distribute the tissue for use in the studies. It was reasoned, for example, that successful applicants to the RFA may not necessarily be those with access to IBD patients - particularly new cases. In addition, it was felt that the provision of tissues by the Foundation could be used in more than one study, and that data may be compared between studies. Following investigations of potential strategies and models, the N etwork recommended that the Foundation set up an independent

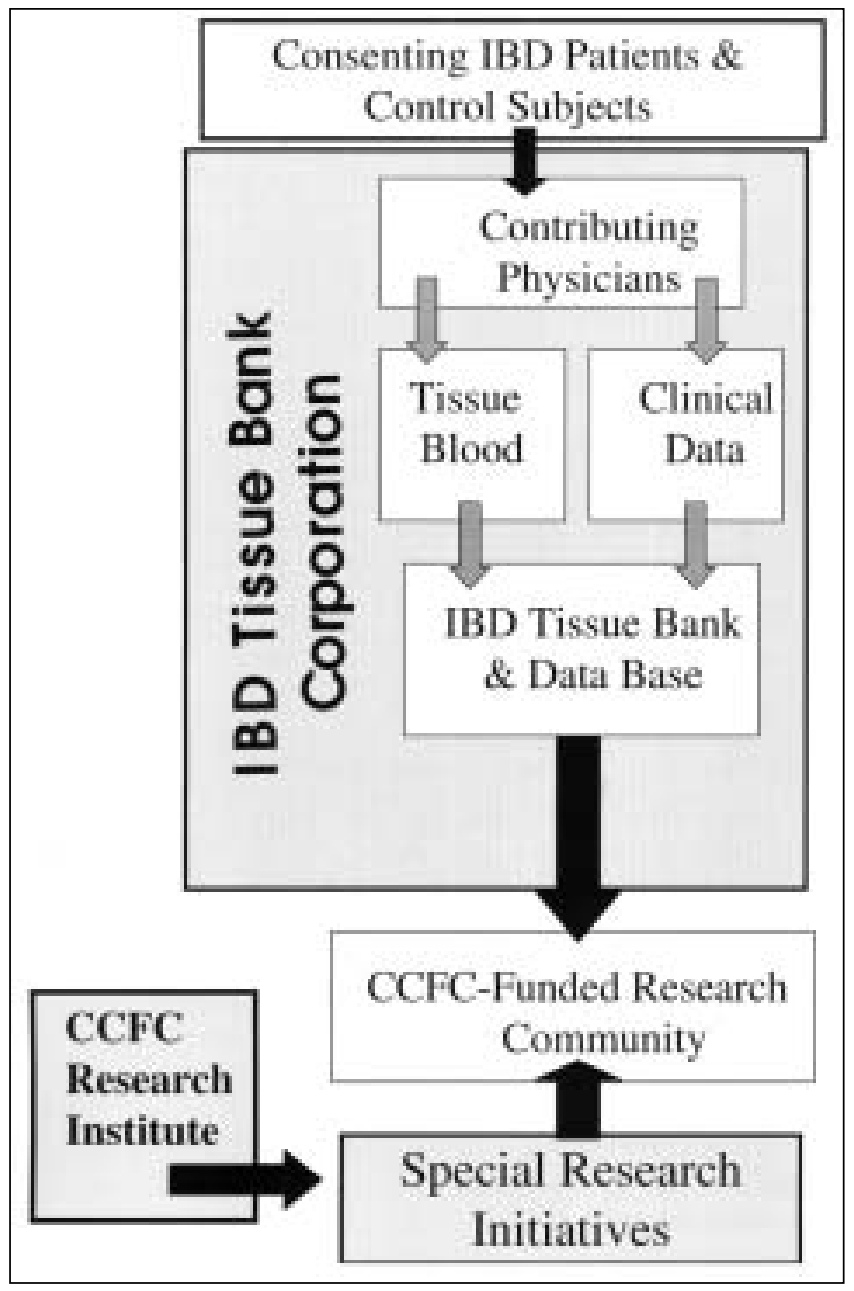

Figure 1) A graphic representation of the $C$ anadian Inflammatory Bowel Disease (IBD) Tissue Bank Corporation. C CFC C rohn's and Colitis F oundation of $\mathrm{C}$ anada

national IBD tissue bank to collect, store and distribute IBD and control tissue as well as manage associated patient data for the planned RFA and future studies in IBD.

\section{THE ESTABLISH MENT OF THE IBD TISSUE BANK}

Following legal consultation and investigations of similar projects in other areas (ie, Ontario cervical smear database), the Foundation established a Tissue Bank Corporation to administer the bank. Tissue collectors as well as investigators using the material or data in the bank first become registered members of the tissue bank. Tissues (biopsies, surgical specimens, blood, serum) are stored and catalogued by Gamma Dynacare ( $M$ ississauga, O ntario). A nonymous clinical information associated with the tissue is stored in an on-line database maintained by A rtificial Intelligence in M edicine (Toronto, O ntario). The interface with donors is via a W eb site www.ibdnet.ca. A graphic representation of the bank is shown in Figure 1.

Written informed consent is obtained from appropriate patients, and a tissue sample number is obtained from the $W$ eb site and permanently associated with that patient. Once collected, the tissue is stored at local institutions at $-70^{\circ} \mathrm{C}$ until 
the diagnosis is verified. If the patient is deemed eligible to be a donor, and pathology criteria for the tissue are met, the tissues are submitted to the bank for storage on ice via courier. Physicians submitting to the bank may retrieve clinical information only on their patients and may choose to use their personal tissue bank database as a more generalized patient database using the available analysis tools in the system. Patients may have their clinical information removed from the database and/or their tissue samples destroyed at any time upon written request. Coded tissue and clinical information is provided only to researchers approved by the bank, and recipients must become members of the tissue bank . Each potential tissue-donor physician must seek ethical approval at his or her own institution. A t the time of writing, the following institutions have been granted ethical approval to collect tissue: M cM aster U niversity (Hamilton, Ontario), Dalhousie U niversity (Halifax, N ova Scotia), U niversity of Manitoba (Winnipeg, $M$ anitoba) and the University of Alberta (Edmonton, A Iberta), with M cM aster and Dalhousie actively contributing tissue already. The following institutions are awaiting ethical approval: University of British Columbia (Vancouver, British Columbia), University of Calgary (Calgary, A lberta), Hospital for Sick Children and Mt Sinai Hospital (Toronto, O ntario), M cG ill U niversity and Hôpital Ste Justine (M ontreal, Q uebec), and H ôpital St-Sacrement (Q uebec City, Quebec). Other institutions are at the early stages of submitting requests for ethics approval.
W hile the N etwork's microbial project requires tissue from newly diagnosed and untreated IBD patients, it is expected that future RFA $s$ will require a broad array of tissues and specimens. It is hoped submissions to the bank will become routine events as the clinical community becomes more familiar with the practice. In the future, the resources of the $C$ anadian IBD Tissue Bank will be available for a variety of C CFC-supported studies, ranging from questions related to the causes of IBD to pharmacogenetics and epidemiological studies.

\section{REFEREN CES}

1. Steinhart $A H$, Feagan $B G, W$ ong $C$ J, et al. Combined budesonide and antibiotic therapy for active C rohn's disease: A randomized controlled trial. G astroenterology 2002;123:33-40.

2. Bernstein CN, Blanchard JF, Rawsthorne P, Wajda A Epidemiology of $C$ rohn's disease and ulcerative colitis in a central Canadian province: a population-based study. A m J Epidemiol 1999;149:916-24.

3. Bernstein CN, Papineau N, Zajaczkowski J, Rawsthorne P, O krusko G, Blanchard JF. Direct hospital costs for patients with inflammatory bowel disease in a $\mathrm{C}$ anadian tertiary care university hospital. A m J G astroenterol 2000;95:677-83.

4. Bernstein CN, Blanchard JF, Kliewer E, Wajda A . C ancer risk in patients with inflammatory bowel disease: A population-based study. C ancer 2001;91:854-62.

5. F Farrokhyar, K M CH ugh, EJ Irvine. Self-reported awareness and use of the International Classification of Diseases coding of inflammatory bowel disease services by $\mathrm{O}$ ntario physicians. $\mathrm{C}$ an J Gastroenterol 2002;16:519-26.

6. M etge CJ, Blanchard JF, Peterson S, Bernstein CN. U se of pharmaceuticals by inflammatory bowel disease patients: $A$ population-based study. A m J G astroenterol 2001;96:3348-55. 


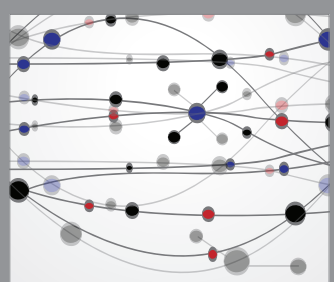

The Scientific World Journal
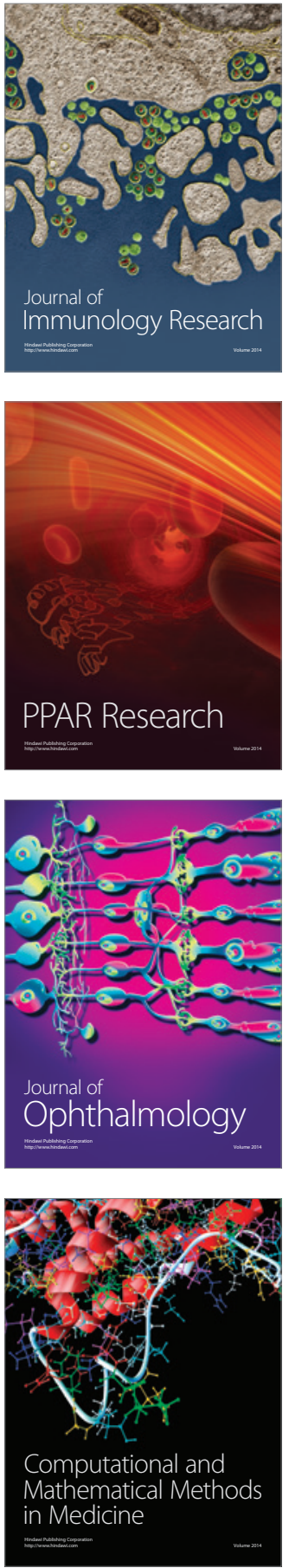

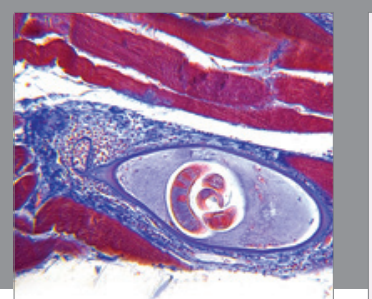

Gastroenterology Research and Practice

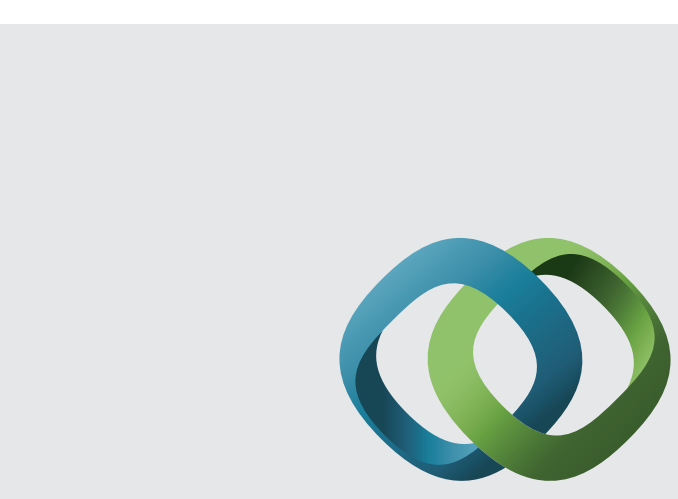

\section{Hindawi}

Submit your manuscripts at

http://www.hindawi.com
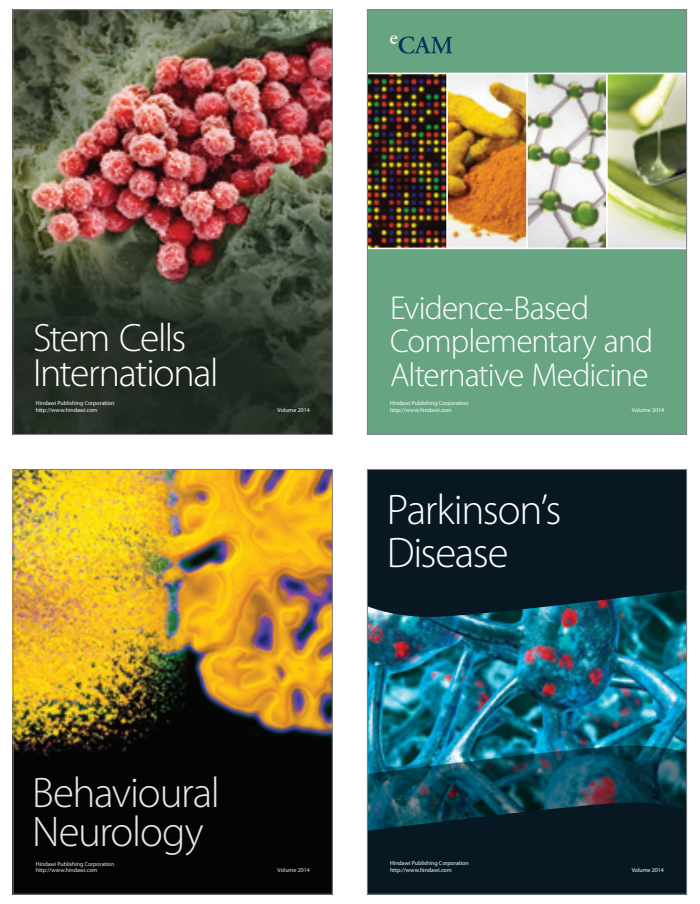
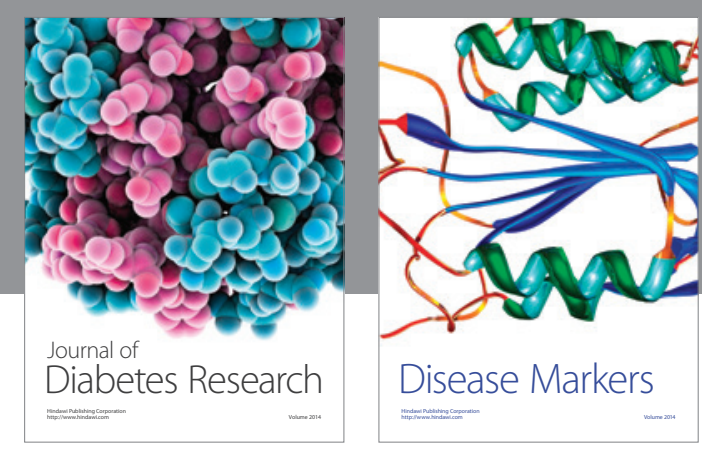

Disease Markers
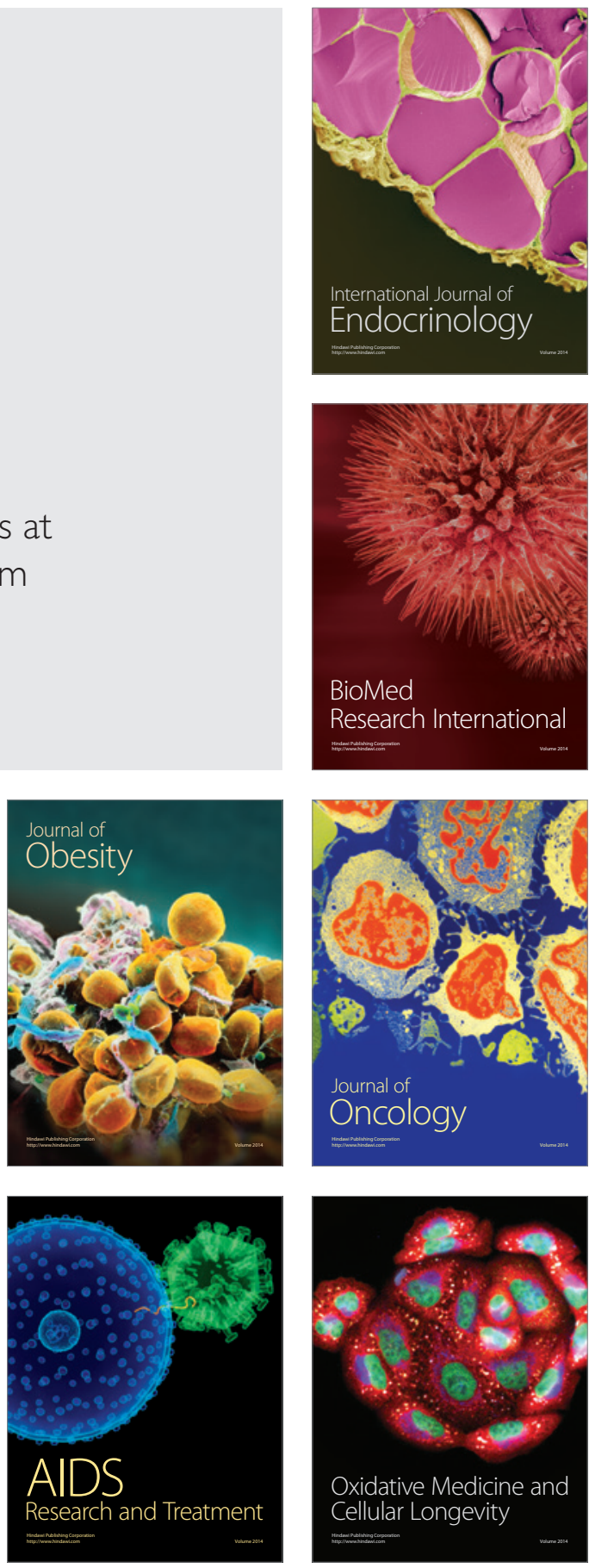